A N N A LES

UNIVERSITATIS MARIAE CURIE-SKŁODOWSKA LUBLIN - POLONIA

VOL. XXIX, 2

SECTIO J

2016

Drohobych Ivan Franko State Pedagogical University, Ukraine

\title{
ANNA FEDOROVYCH
}

f_anna_v@ukr.net

\section{Development of Creative Potential of Future Teachers of Preschool-Age Children in Terms of Pedagogical Higher Education Institutions}

Rozwój twórczego potencjału przyszłych wychowawców dzieci-przedszkolaków w warunkach uczelni pedagogicznych

\begin{abstract}
The article deals with the essence of the concept of "creative potential of the teacher"; it characterises its components (creative abilities, creativity, creative activity), singles out the qualities of a creative specialist; focuses attention on the components of training future teachers of preschool-age children and focuses on the ways of developing creative potential of students in terms of pedagogical higher educational institutions.
\end{abstract}

Key words: creative potential of the teacher; pedagogical creativity; pedagogical training of teachers of preschool-age children; pedagogical higher educational institutions

\section{INTRODUCTION}

Socio-political transformations of a modern society, the integration of Ukraine into European educational space, cause the necessity of improving the national system of higher pedagogical education. One of the priorities of it is training a teacher of preschool-age children. A teacher of a new formation is a researcher, a creative personality, a professional who is characterised by scientific and pedagogical thinking, high spirituality, intelligence, creativity, competence, optimism, and professional flexibility, constant readiness to innovation, self-education and self-development. 
A real teacher must work for the future, be ahead of his time, reac trapidly to societal changes, and adjust his/her own professional activities to social requirements. Thanks to this, a teaching profession is a creative mission, and an educational activity becomes the process of constant creativity.

The concept of pedagogical creativity is studied by scientists in different aspects: as a personality feature; an individual style of activity of the teacher (Sysoieva 1996); a correlation of creative thinking and pedagogical skills (Zagvyazinskij 1987); a scientific-pedagogical style of thinking; a mechanism of pedagogical improvisation.

The teacher's creativity is connected with an original and highly effective solution of educational tasks. It does not mean to create something new, original, because persons (children) and their development are always its "product". Creativity of the teacher is conditioned by his or her creative potential, which is formed on the basis of the accumulated social experience, psycho-pedagogical and subject knowledge, on new ideas, abilities and skills which enable the teacher to find and use innovative forms and methods and thus improve the fulfilling of his or her professional functions, enriching the theory and practice of upbringing and teaching. Creative teachers demonstrate a valuable attitude to their work. They aspire to raise professional qualifications, knowledge and study pedagogical experience.

Analysis of researchers' works confirms that getting higher education is an important stage in the development of pedagogical creativity and in professional formation of the teacher of preschool-age children. Training a future specialist in terms of pedagogical higher educational institutions is a responsible task in the life of the individual, which has its own features, characterised by obtaining professional knowledge, abilities and skills, by involvement in the professionally directed situation of the development. Exactly at this time the basis of teacher's creative potential is laid, which later gets improved in a practical professional activity. That is why higher pedagogical education has to become an environment for the development of creative abilities of future specialists.

The problems of training teachers of preschool educational institutions are studied in the works of national researchers (e.g.: I. Bekh, O. Kononko, T. Pyrozhenko, etc.). The scientists pay attention to enlightening the essence of professional and pedagogical culture, pedagogical creativity, teacher's skills and talent, personal and professional development of the teacher and singling out the components of training teachers (professional self-determination, professional consciousness, professional knowledge and thinking, professional identification, motivation, reflection). However, the problem of the development of creative potential of future teachers in the system of higher pedagogical education is not studied enough. This system should first and foremost deal with improving the content, forms and methods of professional training at a pedagogical university. 


\section{PERSONAL CREATIVE POTENTIAL}

Researchers prove that personal creative potential is a system of internal human resources, which are manifested in a creative activity and conditioned by creativity. This system of complex nature appears on different levels of individuality (biopsychological, psychological, social and spiritual), which ensures stability and integrity of creative manifestations. The development and realisation of creative potential are affected by natural preconditions (general giftedness, inclinations); experience (knowledge, ability, skills); characterological features (independence, initiative, determined qualities, etc.); motivation (goal-setting, self-programming, self-regulation) (Antonova 2006, p. 55).

The essence of creative potential of personality is characterised by the following components: creative abilities, creativity, and creative activity. Creative abilities are closely connected with intelligence and the level of intellectual development, and one needs creativity (the ability to creativity and change) to achieve them. They manifest themselves throughout a human activity. The basis of creative activity is the occurrence and solution to creative tasks, problem situations. The source of creative activity is an internal step of the individual to self-actualisation and self-improvement.

Teacher's work includes many typical, recurring, stable, but also many variable, individual things. In many situations it is necessary to act not according to the standard, but to make decisions based on personal knowledge and values, using creativity, improvising, and reacting rapidly and flexibly to educational situations.

Overall, creative potential is characterised by such features: ease of association (the ability to rapidly and freely switch thoughts, recall the images in mind and create new combinations out of them); critical thinking (the ability to have apprehended statements and to choose one from many alternatives); the readiness of memory (mastering a sufficient amount of systematised knowledge, orderliness and dynamic structure of knowledge); generalising and discarding irrelevant things; creativity as the ability to convert the activity in the creative process (originality, clarity, imagination, activity, sensitivity) (Pobirchenko 2013, p. 223).

Creative potential appears at first intellectually, that is, the teacher thinks over future activities: he or she gets acquainted with the theme of a lesson and tasks, enjoys it, tries to understand it better, looks for the material and updates it, selects methods, techniques, and prepares visual materials, etc.; inner feelings appear subsequently, emotions and creative freedom get mobilised. This way is the most common. Another way goes from a correctly found emotional state to intellectual activity: an emotional mood connected, for example, with impressions of the activities, causes an active intellectual activity, the desire to do something new, acting, teaching, creating, etc. So, we should understand that creative well-being of 
a preschool teacher is always individual and is determined by personal qualities, it also depends on the type of nervous system, character features and is closely associated with temperament, will, reactivity, intuition, originality of speech, etc.

\section{PEDAGOGICAL CREATIVITY EXPERT}

Scientists define important features of pedagogical creativity like a searching problem style of thinking; faulty vision; developed creative imagination, fantasy; personal qualities (curiosity, independence, purposefulness, a willingness to risk), as well as specific leading motives (creative interest, enthusiasm for the creative process, the desire to achieve results, the need to implement oneself). The important conditions of transforming pedagogical activity into creative one are: the awareness of being acreator (director) of the educational process; understanding the nature, significance and tasks of pedagogical activity, its purpose; the perception of the pupil as a person (as a subject of education); the quest for self-realisation, self-confidence, etc.

We should note that pedagogical creativity is limited in time. Quite often, the teacher cannot foresee anything. He or she cannot wait for "inspiration", he or she needs to take quick decisions without adequate logical reasons, relying on intuition. The intuitively correct decision largely depends on the experience, knowledge, abilities, creative potential. In this sense, the creativity of the teacher is manifested in the following aspects: the ability to apply well-known didactic techniques in new standard (or non-standard) situations; the ability to optimally solve pedagogical situationsby means which are often different from the known ones; the ability to improvise (Shvaika 2007, p. 12).

Pedagogical improvisation itself is always connected with creativity as in its terms there is a process of self-actualisation and mobilisation of creative potential of the teacher. It has a pedagogical significance and is an indicator of the quality of educational process in a preschool educational institution. The components of preschool teacher's readiness to pedagogical improvisation are: psychological and pedagogical knowledge, distributed attention, advanced imagination, creative well-being (inspiration, creative search), the ability to communicate and get transformed, speech mastering, reflexive skills, developed intuition, the ability to make quick decisions and realise them (Sereda 2011, p. 51).

\section{DEVELOPMENT TECHNIQUES OF TEACHER'S CREATIVE POTENTIAL}

It is obvious that forming pedagogical creativity and developing creative potential of the future specialist should be carried out in pedagogical higher educational institutions by means of educational activities. Training and professional formation of a teacher provide learning the idea of profession and teacher's per- 
sonality as a future specialist of preschool education, and also of his/her potential professional future. In the educational space of a higher educational institution these ideas are integrated into the individual model of professional growth. That is why the training of future teachers of preschool-age children in terms of pedagogical higher educational institutions should include an appropriately formed way of life, a system of conditions, impacts and opportunities of the professional training of students. It is conditionally possible to single out the following components: theoretical, practical, scientific research, informational, educational and cultural ones, as well as some space for professional skills and creative expression (Kosenko 2011, p. 85). Such components of the educational space are considered as certain organisational forms of the personally professional development of future specialists and the development of their creative potential. Let us consider the essence of such components.

Theoretical training in pedagogical higher educational institutions covers the system of lecture, practical, seminar, laboratory, collective and individual lessons in the disciplines of social and humanitarian, cultural (fundamental) and professionally oriented cycles. The study of academic subjects ("Introduction to Speciality", "Preschool Pedagogy", "General Pedagogy", "Bases of Scientific and Pedagogical Research", "Basic Teaching Skills", "Methods of Preschool Education", etc.), contributes to the development of student's humanistic orientation, professional development, learning the content, forms, methods and technologies of teaching.

The practical component of higher pedagogical education is represented by individual kinds of practice activity: fieldwork, summer pedagogical practice, pedagogical practice in the early age groups, pedagogical practice in preschool educational institutions, survey and methodical practice, assistant and research practice. Students have industrial practice in different types of nursery schools. Its main goal is the mastery of modern methods, forms of professional activity; the formation of professional skills and abilities necessary for independent solution to pedagogical tasks in a real educational process; the development of creative potential and education requirements of systematic professional improvement. During the practice, reflection and requirements (which show student's needs of determination) become of particular value, at this time an adequate idea of the essence of the future professional activity and its creative direction is formed.

Scientific research activity plays an important role in the training of future specialists of preschool education. It involves the organisation of joint creative scientific and educational cooperation of students and teachers. This specific type of activity is organically linked with the educational process and is one of the areas of independent work which focuses on in-depth study of programme contents of academic disciplines, the experience formation of work on the scientific literature, the search for solutions to professional problems. Scientific research work 
contributes to the formation of professionally significant personal qualities of students (independence, purposefulness, concentration, organisation, creativity) and provides for the communication of the student and the teacher, evokes emotions, feelings, contributes to mutual personal and professional growth of subjects of educational space in pedagogical higher educational institutions.

An information space of an educational institution creates additional opportunities for development of creative potential of students. It consists of libraries, reading rooms, teaching rooms, Internet rooms, etc. Thanks to the introduction of information and communication technologies, computerisation of pedagogical process, one can provide an additional reserve of mastering new information which contributes to the formation of ideas system about the modern world. This, in turn, frees up time for other activities, and creative self-development in the educational process.

Cultural and educational component of the training covers the system of extracurricular, sociocultural, educational activities of students. In conjunction with the educational process, the organisation of leisure time affects the formation of creative abilities and creativity, contributes to creative activity, and to raising the level of professional training of future teachers.

Undoubtedly, the interaction with teachers engaged in the educational process plays an important role in the development of creative potential of students. Creative cooperation in theoretical, practical and extracurricular communication characterises the plane of professional skills and creative expression. The style of teaching and pedagogical technologies which are used by teachers should be aimed at supporting individual development of each student and providing him or her with the necessary space for independent decision-making, creativity, choice of contents and methods of learning and behaviour. Such freedom characterises the internal state of the student which is shown in his consciousness and is associated with the manifestation of determined efforts, emotions and creativity. This space is based on the communicative activity of subjects of pedagogical process and foresees the mutual-and self-improvement of teachers and students (Kosenko 2011, p. 87).

Our research (observation of pedagogical process and questioning students of speciality "Preschool Education") proves that the ways of development of creative capabilities and professional creative activity of the future teachers of preschool-age children are:

- motivation of students to pedagogical activity by forming professional values, ideals and beliefs, and developing pedagogical skills;

- development and support of educational interests of students, the classroom atmosphere of joint creativity, collective responsibility, interest in the success of mates; 
- creation of conditions for the acquisition of knowledge aimed at the formation of individual creative experience and primary skills of professional educational activities by involvement in pedagogic practice;

- use of reflection tasks, trainings, etc.;

- setting pedagogical objectives to students, the achievement of which requires a maximum of creativity (organisation and conducting of competitions, contests, the best classes, an educational event, etc.);

- promoting the learning of various ways and systems of processing scientific information;

- getting future teachers into scientific research work on actual problems of preschool pedagogy, into performance of independent research and tasks of creative character.

A significant role in training a creative teacher is played by an active participation of students in studying the problems of educational practice, including an independent search for material on the problems of education, exploring and studying scientific and educational-methodical sources, a thorough analysis of reality through surveillance, research, a search for the ways and methods of solving pedagogical situations. The methods and ways of stimulating creative activity should include: the motivation of their educational-search activity; clear definition of the object and results of the work, its evaluation; enriching the educational environment with new experiences and judgements; providing an attractive creative nature of search activity; encouraging the generation of creative ideas; the practical orientation of educational activity; modelling life situations, using role-playing, joint problem solving, etc.

Therefore, in the higher pedagogical school important technologies in the work with future specialists are: technology of modular training (a system of organisation of educational-cognitive activity, when fundamentally changes the psychology of the student: new circumstances convince him to work on his/her own initiative, systematically); technology of group work (implies cooperation, when future specialists are the subjects of co-curricular activities, which makes the efforts and abilities of each obvious, and this, in turn, is a natural stimulus of a healthy creative competition); technology of problem learning (cognitive contradictions are openly embodied here, and they are implemented when a problem situation appears and causes the need for mastering knowledge and skills, identifying creative potential to solve cognitive tasks); technology of creative development of the individual (learning in cooperation, a method of projects, training of different levels, solution of creative problems and game situations; discussions, where the teacher is a competent consultant, assistant, organiser of pedagogical interaction); technology of forming the stimuli to pedagogical creativity (the process of creating a psychological-pedagogical system, the components of which (the contents, forms, methods, techniques of professional training, the nature of the com- 
munication links among the subjects of the training process) provide conditions for creative activity of students); project technology (involves the solution to the problem, on the one hand by using various methods, training techniques, and on the other hand, by integration of knowledge and skills from various branches of science, technique, creativity), etc.

\section{CONCLUSIONS}

Thus, creative potential is an important characteristic of a modern preschool teacher, which reflects primarily the ability to change. This is an integrative quality that characterises opportunities to raise and solve new challenges in the sphere of educational activities. Creative potential of the teacher is defined by the ability to self-development, to create something new not only in the educational process, but also in itself. The formation and degree of realisation of this ability are determined by external and internal factors, optimality of their combination and consistency.

The development of creative potential of future preschool teachers depends on the abilities to do a creative pedagogical activity, which is closely connected with intellectual and emotional components and common culture of the individual. One activates creativity and forms the need for conversion of the received knowledge and skills under the influence of the conditions of the educational environment. Therefore, the development of creative potential of students depends on forming the atmosphere of creativity, openness and positivism in higher pedagogical educational institutions.

The conditions of effective development of creative potential of future teachers are: stimulation of the creative activity of students by making a necessary educational environment; application of effective methods and forms of organisation of creative activities (pedagogical technologies); high level of development of creative potential of the teacher of a higher educational institution, etc.

\section{ROMANISED REFERENCES}

Antonova, O., Rozvytok tvorchoho potentsialu maibutnoho vchytelia yak faktor yoho profesiinoi samorealizatsii, [in:] I.H.Yermakov, H.M. Nesen (eds.), Zhyttietvorchist osobystosti: kontseptsiia, dosvid, problemy: nauk.-metod. zb., Khortyts'kyi navchal'no-reabilitatsiynyi bahato profil'nyi tsentr, Zaporizhzhya 2006,(ukr.).

Kosenko, Yu., Profesiine stanovlennia maibutnikh pedahohiv doshkilnoi osvity v osvitnomu prostori vyshchoho navchalnoho zakladu, "Naukovyi chasopys Natsionalnoho Pedahohichnoho Universytetu imeni M.P. Drahomanova", Seriia 5: Pedahohichni nauky: realii ta perspektyvy, 2011, no. 25 , (ukr.).

Pobirchenko, O., Rozvytok tvorchoho potentsialu v maibutnikh uchyteliv mystetskykh dyscyplin, "Problemy pidhotovky suchasnoho vchytelia", 2013, no. 8, (Ch. 1), (ukr.). 
Sereda, N., Elementyteatralnoi pedahohiky u formuvanni pedahohichnoi maisternosti, "Teoriia i praktyka upravlinnia sotsialnymy systemamy: naukovo-praktychnyi zhurnal", 2011, no. 2, (ukr.).

Shvaika, L.A., Metodychna robota v DNZ, Osnova, Kharkiv 2007, (ukr.).

Sysoieva, S., Pidhotovka vchytelia do formuvannia tvorchoi osobystosti uchnia, Polihrafknyha,Kyiv 1996, (ukr.).

Zagvyazinskij, V., Pedagogicheskoe tvorchestvo uchitelya, Pedagogika,Moskva 1987, (ru.).

Ziaziuna, I.A. (ed.), Pedahohichna maisternist (Pedagogical skills): pidruchnyk, Vyshcha shkola,Kyiv 2008, (ukr.).

\section{STRESZCZENIE}

W artykule dokonano analizy istoty pojęcia „twórczy potencjał pedagoga”. Zostały tu scharakteryzowane jego składniki (twórcze zdolności, kreatywność, twórcza aktywność) oraz wyodrębniono cechy twórczego fachowcy. Uwagę skupiono na składnikach szkolenia przyszłych wychowawców dzieci-przedszkolaków oraz sposobach rozwoju twórczego potencjału studentów w warunkach instytucji kształcenia pedagogicznego na poziomie wyższym.

Słowa kluczowe: twórczy potencjał; pedagogiczna twórczość; szkolenie wychowawców dzieci-przedszkolaków; pedagogiczne uczelnie 